\title{
INTRODUCTION TO THE SYMPOSIUM ON CLIMATE CHANGE LOCALISM
}

\author{
James Salzman*
}

Of all the topics in the environmental field, climate change is currently the most dynamic, complex, and controversial. Our changing climate and its severe impacts on humans and ecosystems loom as a defining issue of the twenty-first century, pitting the potential disruption of our global climate system against the future of a fossil fuelbased economy. This symposium explores the implications of subnational actors' efforts to address this challenge. The explosion of initiatives and declarations in recent years from outside the federal government, ranging from state and local governments to industry and nongovernmental organizations, has changed the face of climate policy. A number of these efforts cross borders through cap-and-trade programs and policy collaborations. ${ }^{1}$ Such muscular efforts on the local level in the face of federal skepticism and outright opposition to climate initiatives raises fundamental questions about diplomacy, federalism, and preemption.

Since the 1992 UN Framework Convention on Climate Change committed parties to achieve "stabilization of greenhouse gas concentrations in the atmosphere at a level that would prevent dangerous anthropogenic interference with the climate system," ${ }^{2}$ virtually every nation on earth has engaged in intense climate negotiations. The Kyoto Protocol of 1997 provided the most significant "hard law" in the field, establishing binding reduction targets for developed countries. ${ }^{3}$ It proved largely ineffective, however, with the United States not ratifying and many countries failing to meet their targets. ${ }^{4}$

Optimism returned in 2015 with adoption of the Paris Agreement, negotiated at the largest governmental conference in history. Rejecting the top-down, "targets and timetables" strategy of the Kyoto Protocol, the 195 parties instead adopted a bottom-up "pledge and review" approach. Each country determines its own commitments, submitting to the treaty secretariat its nationally determined contribution (NDC). In his first year in office, making good on his campaign pledge, President Trump announced the United States' withdrawal from the Paris Agreement, effective in 2020.

Trump's announcement was immediately met with outrage and pledges of action. The "We Are Still In" declaration released in June 2017 contained pledges from ten states, nine tribes, and 278 cities and counties to maintain the U.S. commitments in the Paris Agreement. ${ }^{5}$ The "Under 2 Coalition" includes commitments from over two hundred governments spanning six continents and forty-three countries to keep global temperature rise under two

* Donald Bren Distinguished Professor of Environmental Law, UCLA Law School and UCSB Bren School of Environmental Science \& Management.

${ }^{1}$ The Pacific Coast Collaborative, for example, is a forum for leadership guided by governors from California, Oregon, Washington, Alaska, and the Premier of British Columbia. In a March 2018 communique, they agreed to cooperate on climate change policies (with Alaska observing). California has been collaborating with states in Brazil and Mexico so that they can offer offsets in California's cap-andtrade program.

2 UN Framework Convention on Climate Change, opened for signature June 4, 1992, 31 ILM 849 (1992) (entered into force Mar. 21, 1994).

${ }^{3}$ Kyoto Protocol to the Framework Convention on Climate Change, Dec. 10, 1997, 37 ILM 22 (1998).

${ }^{4}$ Duncan Clark, Has the Kyoto protocol made any difference to carbon emissions?, THE Guardian (Nov. 26, 2012).

${ }^{5}$ We Are Still In.

\footnotetext{
The American Society of International Law and James Salzman (C) 2018. This is an Open Access article, distributed under the terms of the Creative Commons Attribution licence (http://creativecommons.org/licenses/by/4.0/), which permits unrestricted re-use, distribution, and reproduction in any medium, provided the original work is properly cited.
} 
degrees centigrade and institute deep decarbonization policies. ${ }^{6}$ This group includes thirteen U.S. cities and eleven states, including California and New York. Corporations and pension plans have made similar public declarations about their commitment to battling climate change.

This symposium explores important issues related to this growing presence and assertiveness of nonfederal actors seeking to fill the policy leadership void left by the Trump administration.

The symposium begins with a piece by UCLA's Ann Carlson entitled The Trump Administration's Assault on California's Global Climate Leadership, ${ }^{7}$ highlighting California's leading role in climate change policy. Carlson addresses the current efforts by the Environmental Protection Agency to revoke California's authority to regulate vehicle tailpipe emissions more strictly than the federal government standards. Since Congress' passage of climate change legislation in 2006, California has played an outsized role in climate policy. ${ }^{8}$ Perhaps this is fitting, since it is the sixth largest economy in the world. Governor Jerry Brown has taken a high-profile role in international climate talks and hosted a Global Climate Action Summit in San Francisco in September 2018. ${ }^{9}$ Carlson explains the California exception under the Clean Air Act and how its aggressive standards over the past four decades have dramatically improved local air quality. The state standards for vehicle greenhouse gas emissions through 2025 are equally powerful, both because of the projected reductions in California and because other states have followed California's lead in regulating their own vehicles. Carlson argues that California has played a critical role as a global model, demonstrating that aggressive climate policies not only are compatible with a thriving economy but, in fact, may spur some of the innovation driving economic growth. As a result, the Trump administration's efforts to thwart California's standard-setting authority represent a larger assault on California's technical and policy leadership beyond our borders.

Jean Galbraith, from the University of Pennsylvania, examines the two faces of foreign affairs federalism in her contribution, Two Faces of Foreign Affairs Federalism and What They Mean for Climate Change Mitigation. ${ }^{10}$ She describes the "outer face" of foreign affairs federalism — such as states and cities reaffirming the U.S. commitment to climate action—as a self-selected progressive and internationalist effort. There is also a less considered "inner face" of federalism. Domestically, this dynamic is heterogeneous, engaging actors both supportive of and opposed to climate change policies. States have been split over the Obama administration's Clean Power Plan, for example. The key insight of her piece comes from its focus on how foreign actors can engage with the inner face of foreign affairs federalism, helping empower certain domestic actors and, in so doing, seek to influence federal policy. Foreign officials, for example, can speak directly with red state leaders. They can be more aggressive in issuing travel alerts about particularly recalcitrant states, declining to offer tax incentives to U.S. companies headquartered in these U.S. states, or encouraging their own companies not to establish production facilities in these states. Focusing on the inner face of federalism presents opportunities to influence federal policy through unconventional avenues.

In Changing International Law for a Changing Climate, Daniel Esty of Yale University and Dena Adler of Columbia Law School's Sabin Center for Climate Change Law propose an innovative strategy that leverages the Paris Agreement to strengthen subnational climate efforts. ${ }^{11}$ Recognizing the "Paris Gap," the shortfall between pledged national commitments and the Paris Agreement's target to limit warming well below $2^{\circ} \mathrm{C}$, Esty and Adler seek to further strengthen the bottom-up framework by broadening the formal engagement of subnational

\footnotetext{
${ }^{6}$ Under2 CoAlition.

7 Ann Carlson, The Trump Administration's Assault on California's Global Climate Leadership, 112 AJIL UnBound 269 (2018).

${ }^{8}$ Global Warming Solutions Act of 2006.

${ }^{9}$ Global Climate Action Summit.

${ }^{10}$ Jean Galbraith, Two Faces of Foreign Affairs Federalism and What They Mean for Climate Change Mitigation, 112 AJIL UnBOUND 274 (2018).

${ }^{11}$ Daniel C. Esty \& Dena P. Adler, Changing International Law for a Changing Climate, 112 AJIL UnBound 279 (2018).
} 
and nonstate decision-makers. The Under2 MOU and We Are Still In declarations currently operate outside the international climate regime. Esty and Adler propose a series of mechanisms to link these and other initiatives to the Paris Agreement. Most formally, a Conference of the Parties (COP) could allow mayors, governors, or CEOs to signal their political support of the Paris Agreement in an amendment or annex. More technically, a COP could decide to subject subnational commitments to NDC standards of transparency and reporting, or a COP could "link" with existing or forthcoming compacts between subnational entities. In these clever proposals, Esty and Adler seek to expand the breadth of international law, inviting the mutual engagement and commitment of cities, states, and corporations in delivering climate change solutions.

In her contribution, On Localism and the Persistent Power of the State, Cinnamon Carlarne of the Moritz College of Law at Ohio State University explores the potential of sub- and nonstate climate efforts. ${ }^{12}$ She frames her analysis within the climate policies of the Bush and Obama administrations. In response to the Bush decisions not to promote climate policies, there was a burst of litigation, local legislation, and private commitments all intended to influence the country's emissions trajectory. The Obama administration was aggressive and, in many respects, historic in the sweeping climate initiatives it undertook during that administration's second term but, in the face of a recalcitrant Congress and powerful lobbying by fossil fuel interests, these policies have proven fragile and vulnerable to rapid dismantling by the Trump administration. In short, while the efforts of nonstate actors remain critically important, Carlarne is skeptical that they can lead to pervasive change without the support of the federal government.

The sheer breadth, scale, and rapidity of subnational climate efforts in the United States (particularly since the announced withdrawal from the Paris Agreement) have been impressive. Politically and economically powerful states, influential cities, massive pension funds, major companies, and others have stepped up to push the country toward a more effective response to the varied threats of climate change. In many respects, the system isn't supposed to work this way. Addressing an issue with such obvious international implications as climate change should be spearheaded by the federal government. Necessity remains the mother of invention, however, and we are witnessing an experiment in foreign affairs federalism in real time. The contributions of this symposium provide both hypotheses and new directions for this ongoing experiment, which surely will continue for years to come.

12 Cinnamon P. Carlarne, On Localism and the Persistent Power of the State, 112 AJIL Unbound 285 (2018). 